\title{
Role of Sthanic Chikitsa in Stree Roga: An Ayurveda Review
}

\author{
Available online at www.hjhs.co.in \\ REVIEW ARTICLE \\ Neha N Baxi*,a, Roshan Vijay Vyas ${ }^{\text {b }}$, Nikhil A Baxi ${ }^{\text {c }}$ \\ a Assistant Professor, Streerog evum Prasutitantra Department, Dr VJD, GAM, Patur, Dist- \\ Akola, (M.S.) India.

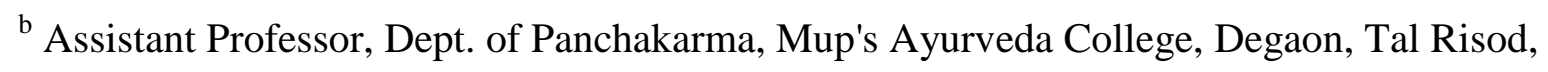 \\ Dt. Washim(M.S.) India. \\ ${ }^{c}$ Associate Professor, Dept. of Samhita Siddhant, Dr. R.N. Lahoti Ayurved Medical College, \\ Sultanpur, Tq. Lonar, Dist. Buldana (MS), India.
}

DOI $\underline{10.22270 / h j h s . v 6 i 4.112}$

\begin{abstract}
Ayurveda put health of women on prime focus and gives detailed description on Stree Roga and their management through Ayurveda approaches. The common gynecological problems are Yonidaha, Yonikandu, Yoni paicchilya, Yoni strava, Yoni karkashata, Vamini and Upapluta yonivyapad, etc. The disturbed pattern of menstruation also causes many gynecological problems associated with female health. Ayurveda explains many ways for curing gynecological disorders especially Yoni Roga requiring local therapeutic measures, Sthanik Chikitsa is one of them which offers therapeutic relieves in various Stree Roga. Yoni-Pichu, Yoni Dhoopan, Yonidhawan, Yoni-Lepana, Uttarbasti, Yoni-Varti and Agnikarma, etc. are common approaches of Sthanik Chikitsa which are useful in many gynecological problems. These all approaches of Ayurveda help to maintain good health status of women and relives symptoms of white discharge, itching, burning micturation, foul smell and discharge, etc. These non-surgical and less invasive techniques offers health benefits to retain reproductive health of female and does not imparts severe side effects. Present article explains role of Sthanic Chikitsa in various Stree Roga.
\end{abstract}

Keywords: Gynecological, Ayurveda, Sthanik chikitsa, Stree Roga.

\section{Introduction}

Women's health is prime concern of medical fraternity; modern as well as traditional medical science put prime focus on women health, in this regards Ayurveda offers several theories and concepts related to the health of women. The good health of female is need of family, society and nation. There are many health issues related to the women health, Ayurveda presented several ways for treating gynecological disorders and Sthanik Chikitsa is one such modality of Ayurveda. Sthanik Chikitsa means utilization of therapeutic measures for local application to treat Sthanik Doshadushti. These local therapies (Figure 1) are considered beneficial for various Stree Rogas related to the vaginal problems. (14)
The general health benefits of Sthanik Chikitsa in vaginal disorders are as follows:

$\checkmark$ Sthanik Chikitsa offers soothing effects thus relives vaginal itching.

$\checkmark$ Sthanik Chikitsa offer astringent property and prevent vaginal discharge.

$\checkmark$ The anti-inflammatory and analgesic drugs used in Sthanik Chikitsa helps to relieve pelvic pain.

$\checkmark$ The anti-bacterial action of drugs used in Sthanik Chikitsa prevents microbial infection and control abnormal vaginal bleeding.

$\checkmark$ These therapies prevent foul smell and burning sensation.

Yoni Pichu (Tampons) 
This is simple method of delivering drug to the site of action in which Pichu of cotton swab wrapped with piece of gauze and tied with thread and immersed in medicated oil. This Pichu of cotton swab inserted inside the vagina to releases medicaments for longer period of time.

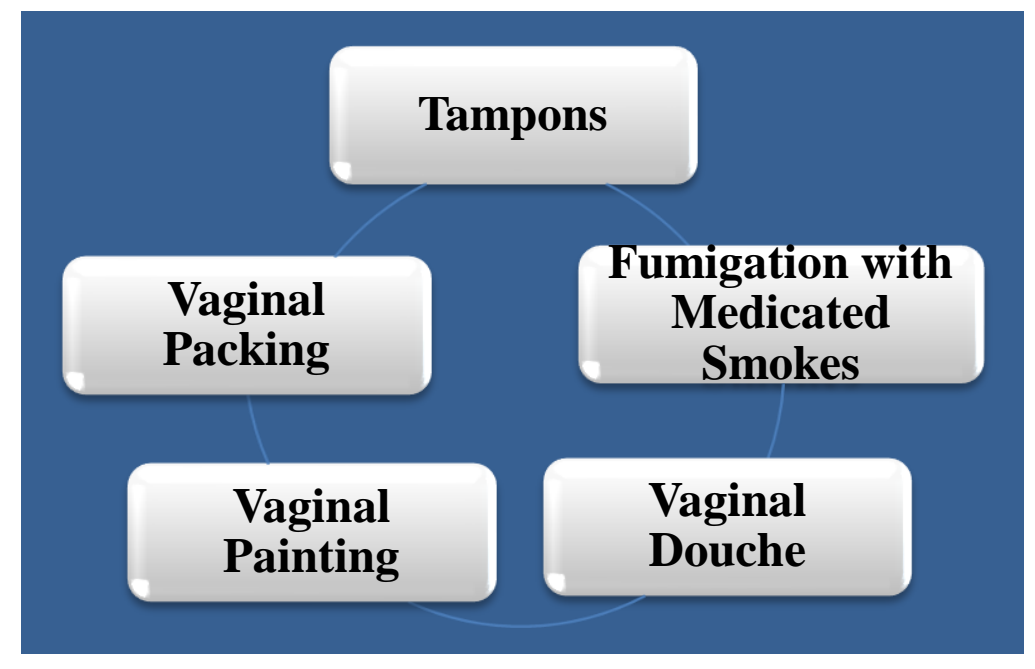

Figure 1: Ayurveda Approaches of Sthanik Chikitsa

The retention ability of circular and elongated Pichu offer advantages of continuous and prolong release of drugs at the site of action. The Yoni Pichu can be used for curing condition like; Yonikandu, Yonidaha, Yonipaka, Yoni strava, Yoni karkashata, Vataj yonivyapad, Vamini and Upapluta yonivyapad, etc. The specific medicines in the form of Pichu can be used for particular purposes. Tampon with Udambar or Triphala kwath is used for Kaphajayoniroga. Pichu soaked with Jatyadi Taila can be used for Mahayoni while Pichu soaked with Dashmoolkwath can be used for Vataja yonivyapada.

\section{Yoni Dhawan/Parisheka (Vaginal douche)}

This involves washing of vagina and vaginal passage with decoction/ liquids of medicines. This process helps to clean or purify vagina and improves healing of vaginal wound. Material like Kshirapak, Kwatha, Taila and Siddha jala, etc. can be used for Dhawan purpose along with water. The aseptic, pain alleviating, wound healing and antimicrobial action of these materials and medicaments offers relives in painful, infectious condition of vagina. Yoni Dhawan is useful for Yonikandu,
Kunapgandhi Artava dushti, Yoni paicchilya and Yoni strava, etc. Specific decoction used for particular purposes, i.e.; decoction of Lodhra and Trikatu is used for Kaphaja artavadushti and decoction of Triphala is used for Kunapgandhi artavadushti.

\section{Yoni Varti (Pessary)}

Varti is used for prolonged therapeutic action to cure infections and restore optimum vaginal health. This therapy mainly indicated for Yoni paicchilya, Kaphaj Yonivyapada, Karnini Yonivyapada and Vipluta Yonivyapada, etc. Powdered Varti made by Yava and Masa is used for Kaphaja yonivyapada.

\section{Yoni Dhupan}

Fumigation of vagina with medicated smoke; mainly indicated for vaginal wound and infection. Fumigation is done for disinfection purpose or to eradicate some specific problems. Yoni Dhupan is considered useful for disinfecting genital organs. Mainly indicates for Yonikandu, Aparasanga, Sutika paricharya and Shwetapradara, etc. The fumigation with Haridra and Brahti is considered good for Yoni kadu while fumigation with Kustha, 
Guggalu and Agara with Ghrita is useful for Sutikaparicharya.

\section{Yoni Lepana}

Yoni Lepana means vaginal painting, this technique offer advantage of higher drug penetration on the vagina, the Lepana increases site of drug application therefore improves ability of drug to penetrate the skin effectively. This therapy is considered good for Vivrutta yoni and Yoni arsha, etc. Lepana with Triphala and Ghrita is useful for Yoni Arsha.

\section{Yoni Purana}

Yonipurana means vaginal packing in which feeling of vaginal cavity done with Churna, Kalka, medicated oil or other form of medicaments. This therapy imparts local therapeutic action of medicines. The therapy considered useful when large amount of drug used for longer duration of time. Yonipurana is considered good for Mahayoni and Prasansini yoni, etc. Yonipurana with Vesawara is useful for Prasansini yoni.

\section{Uttara Basti}

Uttarbasti is best for Vata dosha which mainly involves in gynecological problems. The procedure involves insertion of medicated oil / decoction, etc. into Uttarmarga to treat problems related to the female genital tract mainly associated with Vata Dosha. It should be carried out under aseptic condition with some expertise. Uttarbasti is useful for tubal blockage, for pacifying Vata, to treat diseases of urinary bladder, to cure prolapse uterus \& pelvic pain, also used for menstrual disorders and other Yonivyapada. Basti with oil of Jivaniya group drug is useful for conditions like Shushka yoni, Aticharana and Acharanayoni, etc.

\section{Importance of Sthanik Chikitsa:}

The female suffers with many health issues and gynecological problems not only hampers their life but also affects life of family and society. Poverty, illiteracy, social and religious factors, poor hygiene, physical and mental burden, etc. can affects reproductive health of females. Ayurveda offers safe and effective therapy Sthanik Chikitsa which helps to treat many reproductive problems. Yoni pichu, Yoni dhawan, Uttarbasti, Yoni Lepana and Yonipurana, etc. are major approaches of Sthanik Chikitsa which can treats various reproductive tract diseases of female.

The Sthanik Chikitsa employed medicines locally since vagina shape itself persisted capacity to hold drug in situ for a longer duration, therefore effect of therapy observed for prolong period of time. The absorption of drug is very fast through skin of vaginal tract or membrane, moreover longer time holding capacity of vagina allow release of medicines effectively in continuous manner thus quick onset and prolong action of medicines achieved during Sthanik Chikitsa.

Sthanik Chikitsa helps to deliver medicine for longer period of time and initiate quick response therefore can be given in acute condition. The antiseptic and antibacterial property of Sthanik Chikitsa prevents microbial infection in genital tract. The chances of recurrence of diseases are less due to the compete eradication of disease, Sthanik Chikitsa provides advantages of less invasion and minimal side effects thus can be used for wide variety of disorders of female genital organs. Sthanik Chikitsa provides local therapeutic action, clears blockage and cleans reproductive tract thus maintain optimal health of female genital tract.

\section{Conclusion}

Sthanik Chikitsa is considered safe, effective and cheap therapy for acquiring local therapeutic responses in diseases of female genital tract. The various modalities of Sthanik Chikitsa are free from severe adverse effect and can be used easily with no technical expertise requirement. However aseptic condition, 
maintenance of general hygiene and patient compliance, etc. is some essential requirements which need to be taken care during Sthanik chikitsa. Sthanika Chikitsa acts as Shaman as well as Shodhan Chikitsa, since this therapy offer therapeutic advantages of drugs and also helps to purify or cleans genital tract. Different forms of drug i.e.; Taila, Ghrita, Kwatha and Dhoom, etc. is used for Sthanika Chikitsa in an aseptic condition to release drug at the site of action. This therapy not only relives symptoms of vaginal disorders but also helps to maintain reproductive health of female. (5-10)

\section{Acknowledgements}

We would like to convey our sincere gratitude towards the HJHS Journal for publishing our article.

Financial Disclosure statement: The author received no specific funding for this work.

\section{Conflict of Interest}

The authors declare that there is no conflict of interest regarding the publication of this article.

\section{References}

1. Sushrut, Sushruta Samhita with commentary Nibandh Sangrah commentary of Dulhan Acharya, edited by Vaidya Yadav ji trikamji and Narayan Ram Kavyatirtha, Chaukhamba Sanskrut Sansthan, Varanasi, reprint - edition Vi. Sa. 2067, Sutra sthan chapter- 7/16 Page No 34

2. Sushrut, Sushruta Samhita with commentary Nibandh Sangrah commentary of Dulhan Acharya, edited by Vaidya Yadav ji trikamji and Narayan Ram Kavyatirtha, Chaukhamba Sanskrut Sansthan, Varanasi, reprint - edition Vi. Sa. 2067, Sutra sthan chapter-1/8 Page No 397.

3. Jaymala Shirke, editor Ayurvediya Stree rog vigyana, Edition- 1st, Pune tathagat Prakashan 2003, p- 164.

4. Yogaratnakar edited by Shastri Brahma Shankar, 5th edition, chaukhamba Sanskrit Sansthan, Varanasi, 1993, p- 426.

5. Dhanashree H Mahajan et al. a critical review of sainik chikitsa local therapies adapted in 3 Rover Int.J. Ayu. alt. med, 2014,2(3):28 -35. 7

6. Charaka Samhita, chikitsa sthana edited by Yadavji trikamji Acharya chaukhamba surbharati Prakashan, Varanasi, 3rd edition, 1941.p-638.
7. Astanga sangraha, Uttarasthana, edited by Lalchand Shastri Vaidya, 2nd Edition, Nagpur, Baidyanath Ayurved Bhawan Limited 1981, verse 39/ 49 p680.

8. Charak Samhita, Vidyotini Hindi Com. by Pt. Kashinath Shastri, Part-II, Chikitsasthana 30/61, 62, 108.

9. Charak Samhita, Vidyotini Hindi Com. by Pt. Kashinath Shastri, Part-II, Chikitsa Sthana -30/121.

10. Dhanashri H Mahajan, Manish S. Bhoyar. Efficacy of Triphala Kwath Yoni Dhavan with Triphala siddha ghrita pratisaran. IJRAP April 2013 4(2): 249-252. 